\title{
Preliminary Approach on the Estimation of Ponto-Sarmatic Habitats' Preservation in NE Romania via Herpetological Indicators
}

\author{
Dan Laurentiu STOICA ${ }^{1,3 *}$ and Cristian Valeriu PATRICHE ${ }^{1,2}$ \\ "Al. I. Cuza" University of Iaşi, Faculty of Geography and Geology \\ ${ }^{2}$ Romanian Academy, lasi \\ ${ }^{3}$ Environmental Protection Agency, laşi \\ * Correspondence to: Dan Laurentiu Stoica, “Al. I. Cuza” University of Iaşi, Romania. E-mail: dan_sezu@yahoo.com.

\section{GEOREVIEW}

\section{Article history}

Received: August 2012

Received in revised form: Oct. 2012

Accepted: November 2012

Available online: Jan. 2013

\begin{abstract}
The present scientific approach proposes a preliminary study on habitat suitability and factors' influence using the herpetological indicator Vipera ursinii moldavica and is intended to depict well adapted preservation measures for the Ponto-Sarmatic ecosystems in the context of increased human pressure. The primary goal is to establish an impact hierarchy for the controlling factors. The study incorporates various natural and human related factors via correspondence analysis in order to mark out for the most influential ones. The goal is to enhance understanding of variables' contribution to the process and find appropriate intervention measures as far as the Natura 2000 Management Plans are concerned.
\end{abstract}

KEY WORDS: habitat, anthropic, influence, factor, bio-indicator, herpetological

\section{Introduction}

Landscape ecology and even ecology, in general, greatly relies on the concept of deterministic influence of spatial structure over the ecological processes (Turner et al, 1991). The anthropic activities result in structures' integrity interruption of the ecosystems and may impede, or conversely, facilitate ecological fluxes as territorial movement (Gardner et al., 1993). The interruption of such spatial structures leads to ecological processes functionality loss and populations' decline, ecosystems' health problems and biodiversity outage (Wimberly et al., 2000).

While maps of habitat suitability for highly endangered species are an important issue and require various complex computation methods, the analysis of the factors influencing these species might give punctual insights for proper management measures (Johnson et al, 1992).

Vipera ursinii is a venomous viper and a very widespread species, found from southeastern France all the way to China (Xinjiang). The Vipera ursinii complex displays high genetic diversity as it fosters six subspecies: V. u. ursinii (Bonaparte, 1835), V. u. eriwanensis (Reuss, 1933), V. u. graeca Nilson \& Andrén, 1988, V. u. macrops Méhely, 1911, V. u. moldavica Nilson, Andrén \& 
Joger, 1993, V. u. rakosiensis Méhely, 1893, V. u. renardi Christoph, 1861 (McDiarmid et al., 1999).

This species is considered to be a vulnerable species on the IUCN Red List of Threatened Species, due to habitat destruction caused by changes in agricultural practices and climate change and to collection for the pet trade. (Joger et al., 2008). Vipera ursinii moldavica (Nilson et al., 1993) pertains to the ursinii complex and designates the meadow and steppe vipers of Europe and Asia - the Vipera (Acridophaga) (Nilson and Andrén, 2001). The IUCN Red List of Threatened Species classifies the taxon as critically endangered and emphasizes the need of continuous information updating (The IUCN Red List of Threatened Species, 2012).

Almost one fifth of the European reptiles are considered threatened and the major threats for the European reptiles, both threatened and non-threatened, are habitat loss, habitat fragmentation and degradation. These threats are obviously the result of human activities in nature. Vipera ursinii is probably the most threatened snake in Europe (Ujvari et al., 2002; Edgar \& Bird, 2006). In Eastern Romania, this species is represented by the Vipera ursinii moldavica, which forms populations in grassland habitats from Moldavia and the Danube Delta. All the habitats of the Moldavian meadow viper populations are affected by human activities. Yet, the level of the present anthropic pressure differs (Zamfirescu et al., 2007, 2008, 2009, 2011).

The present study is a preliminary approach intended to quantify human influence on Vipera ursinii moldavica using the natural components influences as comparative data. In this respect Vipera ursinii moldavica represents a very sensitive biological indicator for the monitoring of Ponto-sarmatic habitats along with other more resilient indicators (salt-land habitats, Phragmites habitats, Stemmacantha serratuloides (Georgi) etc.) (Stoica et al., 2011, 2012). We used certain DEM (Digital Elevation Models) derived indices, together with vegetation indices and the distances to well known human activities that might have profound influence on the taxon.

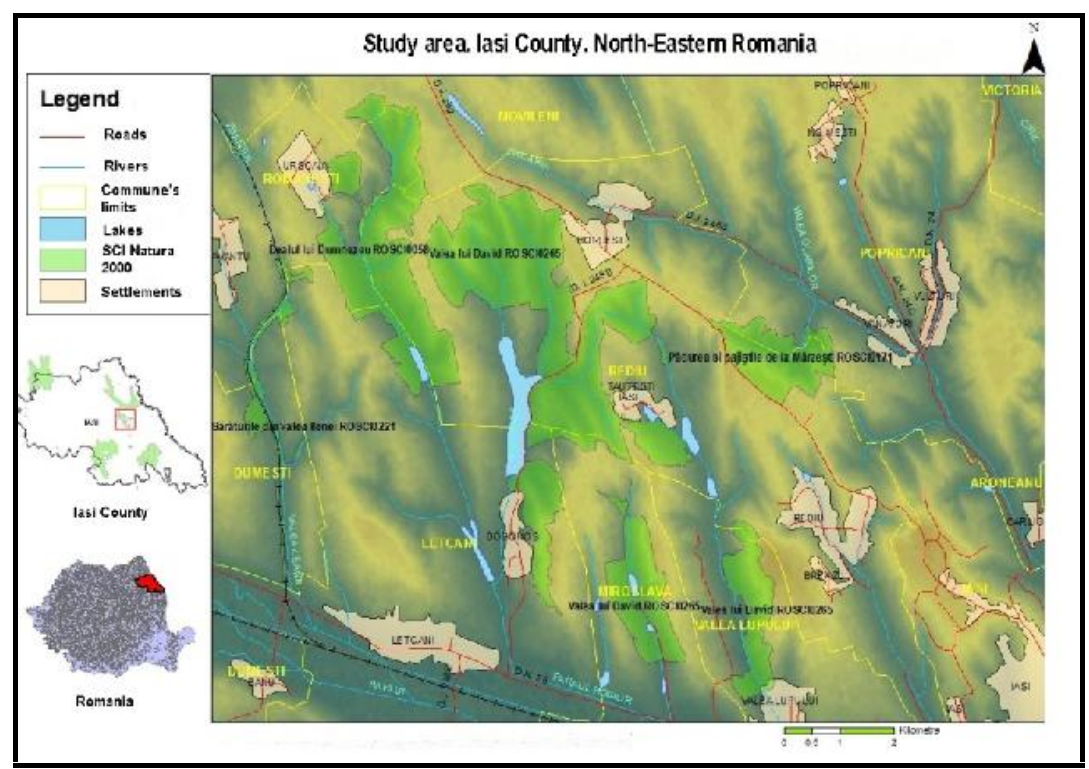

Figure 1. The study area - the most representative Ponto-Sarmatic habitats for Vipera ursinii moldavica of laşi County. This figure is available in colour online at www.georeview.ro. 


\section{Methods}

The study area is centred on the most representative Natura 2000 sites, designated for the meadow viper protection, in the county of laşi: God's Hill (RO SCl 0058), The Forest and Pastures of Mârzeşti (RO SCI 0171) and David's Valley (RO SCl 0265). (Figure 1)

The study area is situated in the southern part of the Jijia-Bahlui Plain and comprises resequent tributaries of Bahlui River developed on clay and marl deposits. The temperate continental climate displays mean annual temperatures of $9.6^{\circ} \mathrm{C}$ and mean annual precipitations of $560 \mathrm{~mm}$. The soil cover is characterized by the presence of salt-rich soils (Solonchaks) and Haplic and Cambic Chernozems, along with a great share of Regosols, Fluvisols and Gleysols.

The computation is based on the location of seven potential habitats marked by Zamfirescu S. R., Zamfirescu O., Popescu I. E., Ion C., Strugariu A. (2008): as Vipera ursinii moldavica presence (Zamfirescu et al., 2008).

The following parameters were brought into the fitting model:

1. SRTM DEM - 30X30 m, USGS (Figure 2)

2. SLOPE inclination in degrees (Figure 2)

3. RUGGEDNESS - amount of elevation difference between adjacent cells of a digital elevation grid (Figure 2)

4. ROUGHNESS - slope convexity (Figure 2)

5. NDVI- Normalized Difference Vegetation Index - healthy vegetation, computed from Landsat TM June 1993 and June 2010

6. ASPECT - exposure to sunlight, degrees (Figure 2)

7. MinDistAccesR - minimum distance to exploitation trails

8. MinDistSettle - minimum distance to permanent settlements

9. MinDistFarm - minimum distance to farms

10. EuclidValley - Euclidian distance to closest valleys' thalweg

11. EuclidRidges - Euclidian distance to closest ridge (Table 1)

Distances were calculated using the 2005 orthophotos 1:5000 delivered by the National Cadastral Agency with data collected between 2003 and 2005. All the parameters were manipulated in Quantum GIS Lisboa 1.8.0, SAGA GIS and XLStat.



Figure 2. Natural factors computation. This figure is available in colour online at www.georeview.ro. 
Table 1. Values computed in the GIS environment - primary data extract

\begin{tabular}{ccccccc}
\hline Vipera sites & DEM & Slope & Roughness & NDVI 2010 & $\begin{array}{c}\text { MinDistAgr } \\
\text { meters }\end{array}$ & $\begin{array}{c}\text { MinDistFarm } \\
\text { meters }\end{array}$ \\
\hline 1 & 160.37 & 7.365 & 10.16 & 0.03333 & 30 & 432 \\
2 & 138.83 & 12.966 & 14.52 & 0.08771 & 35 & 968 \\
3 & 146,21 & 9.856 & 12.22 & 0.06896 & 32 & 369 \\
4 & 91.95 & 3.111 & 4.20 & 0.09803 & 243 & 907 \\
5 & 130.06 & 5.459 & 9.42 & 0.10714 & 61 & 1149 \\
6 & 106.32 & 9.19 & 12.84 & 0.12727 & 70 & 649 \\
7 & 92.76 & 8.799 & 11.71 & 0.6896 & 252 & 1044 \\
\hline
\end{tabular}

Correspondence analysis is a geometric technique for displaying the rows and columns of a twoway contingency table as points in a low-dimensional space, such that the positions of the row and column points are consistent with their associations in the table. The goal is to have a global view of the data that is useful for interpretation.

The significance of association is tested by the Chi-square test, but this test provides no information as to which are the significant individual associations between row-column pairs of the data matrix. Correspondence analysis shows how the variables are related, not just that a relationship exists (Greenacre, 1983). The first step of the analysis is to test if there is independence between rows and columns. If Chi-square (Observed value) exceeds Chi-square (Critical value) one should reject the null hypothesis ( $\mathrm{HO}$ ) and accept the alternative hypothesis $(\mathrm{Ha})$, stating that there is dependence between the rows and the columns (Table 2).

Table 2. Results from Chi-square test

\begin{tabular}{lc}
\hline Chi-square (Observed value) & 3946,334 \\
Chi-square (Critical value) & 92,808 \\
p-value & $<0.0001$ \\
alpha & 0,05 \\
\hline
\end{tabular}

As the computed $p$-value is lower than the significance level alpha $=0.05$, one should reject the null hypothesis $\mathrm{HO}$, and accept the alternative hypothesis $\mathrm{Ha}$, there is a link between the rows and the columns of the table. In correspondence analysis, we are essentially looking for a lowdimensional subspace, which is as close as possible to the set of profile points in the highdimensional true space. The objective of correspondence analysis is to discover which subspace $S$ minimizes the above criterion (Dodge, 2003).

Correspondence analysis determines the principal axes of inertia and for each axis the corresponding eigenvalue, which is the same as the inertia of the cloud in the direction of the axis. The first factorial axis is the line in the direction of which the inertia of the cloud is a maximum. The second factorial axis is, among all the lines that are perpendicular to the first factorial axis, the one in whose direction the inertia of the cloud is a maximum, and so on. The optimal subspace is a subspace spanned by the principal axes. The inertia of a profile along a principal axis is called the Principal Inertia (Figure 3).

Geometrically, the principal inertia is the weighted average of the Chi-squared distances from the centroid to the projections of the row profiles on the respective principal axis (Greenacre, 2007). 


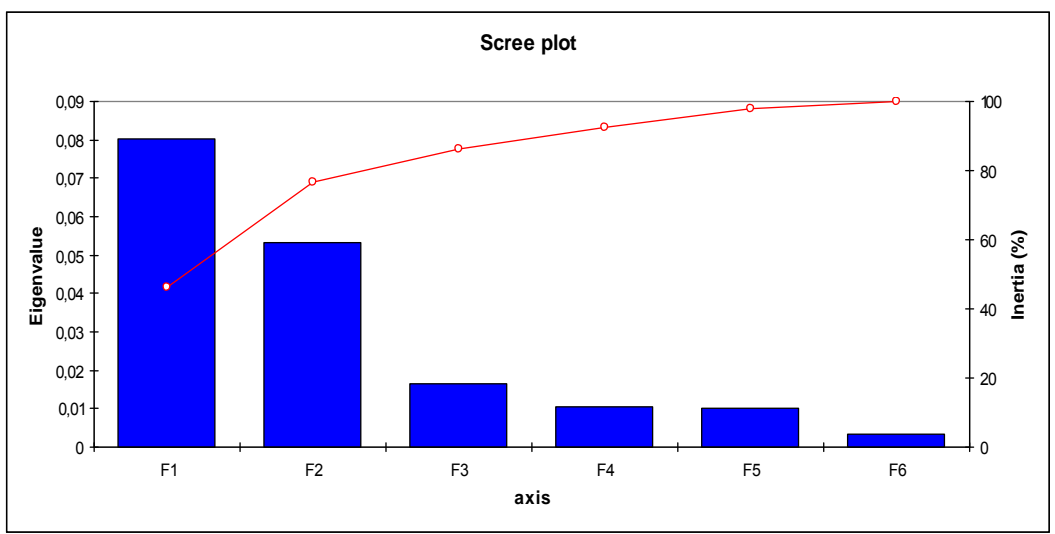

Figure 3. Inertia computed from the primary data - Table 1. This figure is available in colour online at www.georeview.ro.

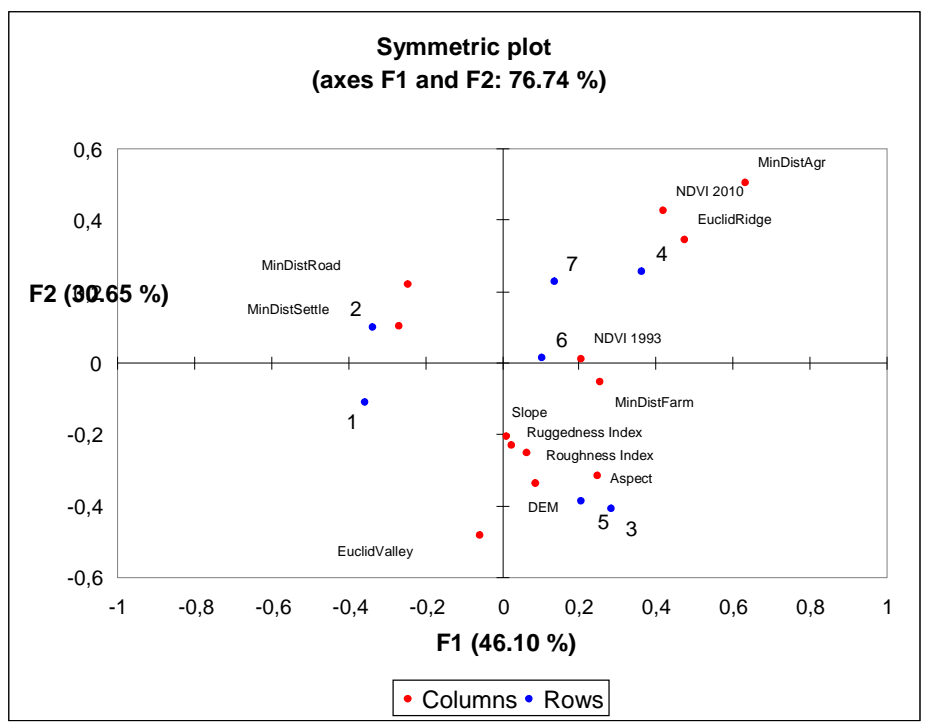

Figure 4. Correspondence analysis plot 1; columns indicate Vipera sites, rows indicate control factors. This figure is available in colour online at www.georeview.ro.

\section{Results}

In Figure 4, the first axis (F1), the one that holds the highest explanatory percentage $(46,10 \%)$ clearly separates 3 variables with lower contribution to the species location (MinDistRoad, MinDistSettle and EuclidValley). The natural factors: slope, DEM, aspect, ruggedness, roughness, except NDVI, have a constant but not determinant contribution to specie's presence. Only location 3 and 5 are better explained by the natural factors. The second axis F2 (30,65\%) depicts an obvious distinction between the role of human factors and the natural elements (all except MinDistFarm) and their predominance over the natural elements. 
The association between Vipera presence dots (in blue) and the factors dots (in red), in other words, between rows' and columns' Chi distances from the barycentre is not to be interpreted per se, as suggested in the symmetric plot. Yet, the tendencies might show different stages of causality. Hence, Point 2 is favoured by great distances to settlements and roads. The situation is also characteristic for Point 1 but at a lower explanatory level. Points 3 and 5 display minimum distances to settlements, roads, farms and agriculture and this could be the reason why they are much related to natural factors (slope, DEM, aspect, etc). The majority of points/rows are explained by MinDistFarm, as central feature, leading to the idea that this could be the most influential factor to Vipera's locations.

Another view point emphasizes that NDVI displays great influence as it gravitates in the presence of points 4, 6 and 7 . These points stand for proper habitat spots that are fairly distributed in relation to the human induced factors. The study considers the NDVIs of June 1993 and June 2010 , none of them pertaining to the supporting study years (2007-2008) when locations where depicted. The purpose was to show time variability over proper vegetation conditions and the influence to Vipera's presence. One can observe that the 1993 NDVI is more explanatory for the majority of points while the NDVI of 2010 tends to have a weak connection with all of the points. This may be interpreted as degradation of vegetation cover and species' tendency to look for safe places instead of well vegetated places.

EuclidValley and MinDistAgr seem to play low attraction and/or influence over the species' presence.An additional issue to improve the results is to look for outliers as variables that distort the analysis. The effect of such outliers is to dominate the interpretation of one or more of the axes. In doing so, the remaining row and/or column points tend to be tightly clustered in the resulting plots and thus difficult to interpret. Potential outliers may be detected by seeking rows or columns that have both high absolute co-ordinate values and high contributions (Figure 5).

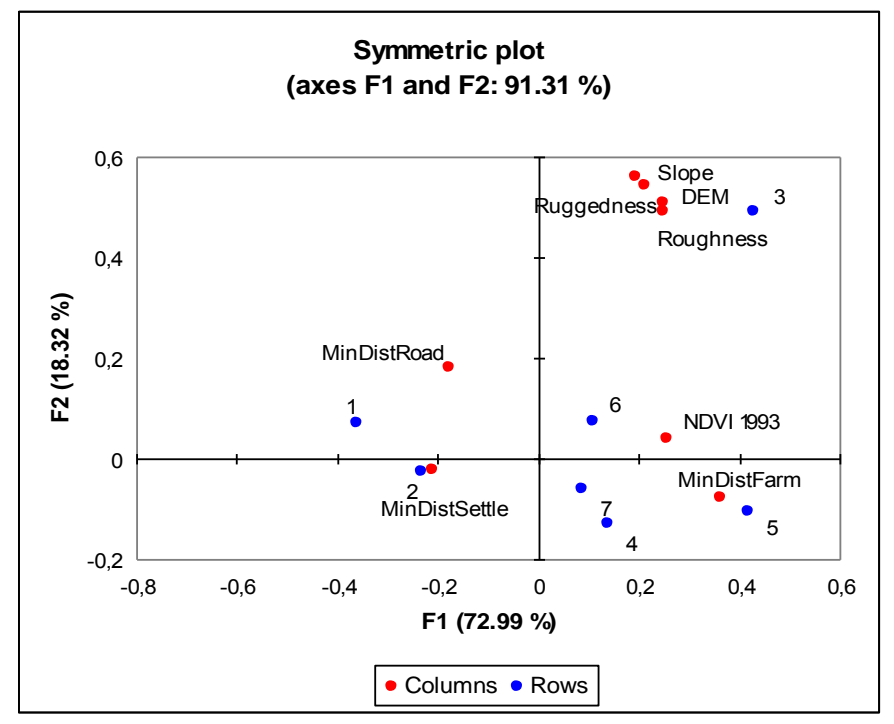

Figure 5. Correspondence analysis plot 2; columns indicate Vipera sites, rows indicate control factors. This figure is available in colour online at www.georeview.ro.

In this case the outliers that display the greatest absolute values are: MinDistAgr, EuclidRidge and NDVI 2010. If we remove these outliers the structure of the correspondence analyses does not change but there are certain secondary re-arrangements reported especially for F2. 
One important observation is that the $2 \mathrm{D}$ plot now explains far more than the first one in $\mathrm{F} 1+\mathrm{F} 2$ with $91.31 \%$ instead of previous $76.74 \%$. Now the majority of points are explained by NDVI (healthy vegetation) and MinDistFarm (four instead of previous three) and the natural factors tend to share even less explanatory contribution. The natural factors become positive in axes 2 , thus they become outliers, themselves. Only point 3 is now related to these factors as the aspect which controls point 5 was removed.

\section{Conclusions}

It seems that, even after the removal of certain outliers, the MinDistFarm holds the position of central feature in explaining the seven Vipera locations. One important aspect is that MinDistFarm may be a measure of grazing impact as long as exact numbers and fluxes of the live stock are hard to quantify. The farm factor should be expected for high impact since hundreds of domestic animals roam the valleys, along with shepherd dogs and watching personnel. In this respect the greatest share of human induced movement inside the protected area is generated by farms. The direct results of these activities are Vipera killings, habitat degradation and biodiversity loss. In this respect the Management Plans should include strict measures toward farms locations and activities in connection with the above mentioned Natura 2000.

While there is much to be done in the understanding of factors' key role over the suitable seminatural habitats for endangered species in the region, the present approach, might lead to alternative tracks in attaining better conservative measures.

The correspondence analysis seems to be fit for exploratory techniques where lots of variables are to be counted in. In this respect, future approaches should look for more and appropriate variables to be considered in the analysis process. That is why the study is opened to suggestions, comments and expertise that might lead to better results.

\section{Acknowledgements}

This study was carried out with support from project POSDRU/89/1.5/S/49944 project, coordinated by "Alexandru loan Cuza" University of laşi. The authors wish to thank Dr Stefan R. Zamfirescu for fruitful guidance and expertise in relation with Vipera ursinii moldavica.

\section{References}

Dodge Y. 2003. The Oxford Dictionary of Statistical Terms, OUP ISBN 0-19-850994-4.

Edgar P., Bird, D.R. 2006. Action plan for the Conservation of the MeadowViper (Vipera ursinii) in Europe. Convention on the Conservation of European Wildlife and Natural Habitats, Standing Commitee, 26th meeting, Strasbourg, 27-29 November, T-PVS/Inf (2006) 21.

Gardner R. H., O’Neil R.V., Turner M.G. 1993. Ecological implications of landscape fragmentation. pp 208-226 Springer-Verlag, New York.

Greenacre M. 1983. Theory and Applications of Correspondence Analysis. London: Academic Press. ISBN 0-12-299050-1. 
Greenacre M. 2007. Correspondence Analysis in Practice, Second Edition. London: Chapman \& Hall/CRC.

Joger U., Crnobrnja Isailovic J., Vogrin M., Corti C., Sterijovski B., Westerström A., Krecsák L., Pérez Mellado V., Sá-Sousa P., Cheylan M., Pleguezuelos J.M., Sindaco R. 2008. Vipera ursinii. IUCN Red List of Threatened Species.

Johnson A. R., Milne B. T., Wiens J. A., Crist T. O. 1992. Animal movements and population dynamics in heterogeneous landscapes. Landscape Ecol. 7:63-75.

McDiarmid R.W., Campbell J.A., Touré T. 1999. Snake Species of the World: A Taxonomic and Geographic Reference, vol. 1. Herpetologists' League. 511 pp. ISBN 1-893777-00-6 (series). ISBN 1-893777-01-4 (volume).

Nilson G., Andrén C. \& Joger U. 1993. A re-evaluation of the taxonomic status of the Moldavian steppe viper based on immunological investigations, with a discussion of the hypothesis of secondary intergradation between Vipera ursinii rakosiensis and Vipera (ursinii) renardi. Amphibia-Reptilia 14: 45-57.

Nilson G. and Andrén C. 2001. The meadow and steppe vipers of Europe and Asia - the Vipera (Acridophaga) ursinii complex. Acta Zoologica Academiae Scientiarum Hungaricae 47(2-3): 87-267.

Stoica D. L. \& Sîrbu C. 2011. Interdisciplinary Approach on Assessing the Conservation Status of Rare Plants in Urban Proximities. Case study - Stemmacantha Serratuloides. 11th International Multidisciplinary Scientific GeoConference SGEM2011, Conference Proceedings 3: 443-450. ISSN 1314-2704, June 20-25, DOI: 10.5593/sgem2011/s20.140.

Stoica D.L., Patriche C. V., Sîrbu C, Pîrnău R., Roşca B. 2012. GIS and RS soil-vegetation correlations for continental salt-lands habitats in NE Romania. Eurasian Journal of Soil Science 1(2):75-80.

Stoica D.L., Sîrbu C., Patriche C. V. 2012. Continental Salt Land Habitats Conservation State Related to Natura 2000 Sites. RO SCl Ileana Valley Application, lasi County. Present Environment and Sustainable Development 6(2).

Zamfirescu Ş.R., Zamfirescu O., Ion C., Popescu I.E. 2007. Research on the habitats of Vipera ursinii moldavica populations from laşi County. Analele Ştiinţifice ale Universităţii "Al.ı.Cuza" laşi, s. Biologie Animală 53:159-166.

Zamfirescu Ş.R., Zamfirescu O., Popescu I. E., Ion C., Strugariu A. 2008. Vipera de stepă (Vipera ursinii moldavica) şi habitatele sale din Moldova (Romania). Editura Universitatii „Al.I. Cuza” laşi, Romania.

Zamfirescu Ş.R., Zamfirescu O., Popescu I.E., Ion C. 2009. Preliminary data on the population characteristics of Vipera ursinii moldavica from "Dealul lui Dumnezeu" (Iaşi County, Romania) with notes on conservation. North-Western Journal of Zoology 5(1):85-96.

Zamfirescu S. R. et al. 2011. Human Impact On Habitats of the Meadow Viper (Vipera Ursinii) in Eastern Romania, Analele Stiintifice ale Universității „Al. I. Cuza” Iasi, s. Biologie animală, Tom LVII.

Turner M. G., Gardner R. H. 1991. Quantitative methods in landscape ecology. Springer-Verlag, New York.

Ujvari B, Madsen T, Kotenko T, Olsson M, Shine R, Wittzell H. 2002. Low genetic diversity threatens imminent extinction for the Hungarian meadow viper (Vipera ursinii rakosiensis). Biological Conservation 105:127-130. 
Wimberly M. C., Spies T. A., Long C. J., Whitlock C. 2000. Simulating historical variability in the amount of old forests in the Oregon Coast Range. Conservation Biology 14:167-180.

*** The IUCN Red List of Threatened Species. 2012. European Reptile \& Amphibian Specialist Group 1996. Vipera ursinii ssp. moldavica. In: IUCN 2012. IUCN Red List of Threatened Species. Version 2012.2.

** XLSTAT Tutorial, http://www.xlstat.com/en/support/tutorials/. 